\title{
THE EFFECTIVENESS OF QUANTUM LEARNING TO INCREASE MOTIVATION AND MASTERY OF ARABIC VOCABULARY OF LEARNERS
}

\author{
Munawarah, Haniah, Kamaluddin Abunawas \\ Universitas Islam Negeri Alauddin Makassar \\ email: munawarahsultan95@gmail.com
}

\begin{abstract}
This research aims to see the difference in the effectiveness between the quantum learning model at the experiment class and TPS (think pairs share) model at the controlling it is observed from the learning motivation and mastering the students' Arabic Language vocabulary. This research uses the quantitative method, which is quasi-experiment. The data collection method is a questionnaire, test, and observation with independent sample t-test data analysis. This research collects data and serves it systematically by using SPSS 22 for windows application. The results showed that quantum learning models in practical classes and TPS learning models (think pairs share) in control classes are classified as useful because they increase average value. This indicates that using various learning models can increase the motivation and mastery of learners' Arabic vocabulary so that educators do not just monotonously apply one model in learning. Educators are also required to use many models (multimethods) because varied learning models can positively influence increasing motivation and mastery of Arabic vocabulary.
\end{abstract}

Keywords: Learning effectiveness; Learning Motivation; Mastery of Arabic Vocabulary.

\begin{abstract}
Abstrak
Penelitian ini bertujuan untuk melihat perbedaan keefektifan antara model pembelajaran quantum learning pada kelas eksperimen dan model pembelajaran TPS (think pairs share) pada kelas kontrol ditinjau dari motivasi belajar dan
\end{abstract}


penguasaan kosa kata bahasa Arab peserta didik. Dalam penelitian ini menggunakan kuantitatif dengan jenis quasi eksperimen, di mana metode pengumpulan data yang digunakan adalah angket, tes dan observasi dengan teknik analisis data yang digunakan adalah uji independent sample t-test dengan aplikasi program SPSS 22 for windows. Hasil penelitian menunjukkan, bahwa model pembelajaran quantum learning pada kelas eksperimen dan model pembelajaran TPS (think pairs share) pada kelas kontrol tergolong efektif karena mengalami peningkatan nilai rata-rata. Hal ini mengindikasikan, bahwa penggunaan model pembelajaran yang bervariasi dapat meningkatkan motivasi dan penguasaan kosakata bahasa Arab peserta didik sehingga pendidik tidak hanya monoton menerapkan satu model saja di dalam pembelajaran. Pendidik juga dituntut untuk menerapkan banyak model (multi method), karena pada hakikatnya penerapan model pembelajaran yang bervariasi dapat memberikan pengaruh positif terhadap peningkatan motivasi dan penguasaan kosa kata bahasa Arab.

Kata Kunci: Efektivitas Pembelajaran; Motivasi Belajar; Penguasaan Mufradat.

\section{A. Introduction}

The lack of quality of the learning process is a problem faced in the world of education today. Learners in the learning process are less motivated in the development of their thinking abilities. The learning process carried out in the classroom emphasizes learners' ability to memorize various information submitted. They must remember and collect multiple information without being required to understand the information that is recognized. As a result, when students have completed their learning or graduated from school, they are theoretically capable but less able to apply them. ${ }^{1}$

Today, experts are concentrating on exploring effective Methods of Teaching Arabic, which can be seen in people's success in America and Europe in mastering Arabic. ${ }^{2}$ The teaching method is essential in achieving educational objectives, especially in the teaching and learning process. An effective learning process can compensate for various problems related to learning activities, such as the weak absorption of learners, the lack of facilities, and others. Thus, it becomes a challenge for the Indonesian education world, especially for religious schools and public schools that teach Arabic as their subjects. However, the problem is how Arabic teachers can develop their teaching systems to be motivated to learn Arabic.

MTs As'adiyah Banua Baru, Kab. Polewali Mandar is a school-based on Islam and also makes Arabic subjects the main subjects. After initial

\footnotetext{
${ }^{1}$ Wina Sanjaya, Strategi Pembelajaran Berorintasi Standar Proses Pendidikan (Jakarta: Kencana, 2006), 1.

${ }^{2}$ Azhar Arsyad, Bahasa Arab dan Metode Pengajarannya: Beberapa Pokok Pikiran (Yogyakarta: Pustaka Pelajar, 2003), 12.
} 
observations, it was found that students were less interested and motivated by Arabic subjects marked by, often students complained of difficulties when learning Arabic, often in and out of class while the lesson was taking place and considered, that Arabic subjects as subjects that are not interesting and difficult to understand so that students are less interested and motivated in learning Arabic. ${ }^{3}$ The problem's effect is to make it easy for students to forget the Vocabulary learned and become lazy to get used to Arabic conversation. Besides, the methods and media used in the learning process are still fixated on textbooks in a formal atmosphere in the school, so that things are always felt less to create a conducive, varied and fun atmosphere for students.

One of the studies that showed the difficulty of learners in learning Arabic is research that Muhammad Beben Satria Ardiansyah has done. In the study, it was written that students' Arabic language ability in the school is relatively low due to different backgrounds, lack of motivation, and students' ability to read Arabic texts. ${ }^{4}$

In the initial observation in MTs As'adiyah Banua Baru, it was also found that teachers use conventional learning models that tend to be monotonous and less varied in the delivery of materials, and also sometimes use tps type learning models (think pairs share). Although the TPS model is useful in optimizing learners' participation to be active and triggering learners to express opinions, the TPS model is only focused on the method of discussion of small groups in the learning process. So in this study, one of the techniques used by researchers, namely by using quantum learning models, is to increase motivation and mastery of Arabic vocabulary learners.

To see the quantum learning model's effectiveness, researchers will compare this quantum learning model with the cooperative model of TPS type applied to Arabic language learning in the school. If teachers or learners' problems, if not sought solutions, will undoubtedly impact the quality of education, and learners will not achieve national education goals. So the learners will feel that Arabic is difficult, and they will be less motivated to learn. As a result, their Vocabulary will not improve.

Based on these problems, this study was conducted to measure quantum learning's effectiveness to increase motivation and mastery of Arabic vocabulary of learners in MTs As'adiyah Banua Baru, Polewali Mandar Regency.

\footnotetext{
${ }^{3}$ Observations at MTs As'adiyah Banua Baru, Polewali Mandar Regency, March 11, 2019.

${ }^{4}$ Muhammad Beben Satria Ardiansyah, "Analisis Faktor Kesulitan Membaca Teks Berbahasa Arab Pada Siswa Kelas X IIS 1 Madrasah Aliyah Negeri Wonokromo Bantul Yogyakarta Tahun Ajaran 2016/2017" (Skripsi, UIN Sunan Kalijaga Yogyakarta, 2017), http://digilib.uin-suka.ac.id/25252/.
} 


\section{B. Theoretical Description}

\section{The Effectiveness of Quantum Learning}

Afifatu Rohmawati explained that "The effectiveness of learning is a measure of the success of a process of interaction between learners and between learners and educators in educational situations to achieve learning objectives." ${ }^{5}$ Deassy and Endang stated that the "effectiveness of learning is a useful learning and aims for learners that allow learners to learn specific skills, science and attitudes easily, enjoyable, and can be completed learning objectives as expected."6 So, it can be concluded that learning effectiveness is a measure of the learning process's success in achieving the learning objectives.

Quantum is an interaction that turns energy into light. Porter et al. interpret quantum as an interaction that converts energy into light. ${ }^{7}$ The medium word "learning" means learning, learning, knowledge. ${ }^{8}$ While etymologically, "quantum learning" means acceleration in learning or learning process in a short time and with optimal results. A term similar to quantum learning is "learning acceleration", a teaching and learning process that allows learners to learn with optimal effort, impressive speed, and accompanied by excitement. An effective learning atmosphere is created through a mixture of entertainment, healthy emotions, games, positive ways of thinking, and physical fitness. ${ }^{9}$

Bhaddin said: "The skills that will be taught to the students in quantum learning are separated into two categories. The first one is quantum working strategies, quantum note-taking, memory, mind maps, quantum writing, and reading techniques known as academic skills. The second one is described as lifelong learning skills. And these consist of creative problem-solving techniques, eight keys of excellence, leadership skills, self-confidence feeling, responsibility, motivation, and effective communication skills. ${ }^{110}$

${ }^{5}$ Afifatu Rohmawati, “Efektivitas Pembelajaran," Jurnal Pendidikan Usia Dini 9, no. 1 (2015): 15-32, http://journal.unj.ac.id/unj/index.php/jpud/article/view/3491.

${ }^{6}$ Deassy May Andini dan Endang Supardi, "Kompetensi Pedagogik Guru Terhadap Efektivitas Pembelajaran Dengan Variabel Kontrol Latar Belakang Pendidikan Guru," Jurnal Pendidikan Manajemen Perkantoran (JPManper) 3, no. 1 (2018): 1-7, https://doi.org/10.17509/jpm.v3i1.9450.

${ }^{7}$ Bobbi DePorter dan Mike Hernacki, Quantum Learning: Membiasakan Belajar Nyaman dan Menyenangkan, trans. oleh Alwiyah Abdurrahman (Bandung: Kaifa, 2011), 49.

${ }^{8}$ John M. Echols dan Hassan Shadily, Kamus Inggris Indonesia (Jakarta: Gramedia Pustaka Utama, 2000), 352.

${ }^{9}$ DePorter dan Hernacki, Quantum Learning: Membiasakan Belajar Nyaman dan Menyenangkan, 14.

${ }^{10}$ M. Bahaddin ACAT dan Yusuf Ay, "An Investigation the Effect of Quantum Learning Approach on Primary School 7th Grade Students' Science Achievement, Retention 
From the explanation above, it can be concluded that quantum learning model learning is learning that can create interaction and activeness of learners so that the ability of talent and potential learners can develop, which is ultimately able to improve learning achievement by removing learning barriers through the use of appropriate ways and tools and following the subject matter so that learners can learn quickly. In the quantum learning model's learning process, there is alignment and empowerment of the learning community. Teachers and learners are involved in the learning process both feel happy and work together to achieve maximum results.

Bobbi DePorter and Mike Hernacki said in the application of quantum learning models with the concept of learning how to learn, quantum learning develops several learning skills, such as organizing a comfortable and pleasant learning environment, finding suitable learning methods, fostering positive attitudes, applying AMBAK (What Benefits For Me), improving mind density, making effective notes, improving memory, improving reading skills and improving writing techniques. ${ }^{11}$

\section{TPS Learning Model (think pairs share)}

Miftahul Huda explained that "learning models are defined as an overall picture of complex learning with various techniques and procedures that are an important part". In the complexity of learning models, there are methods, techniques, and procedures that intersect. ${ }^{12}$ So the learning model is a complex learning device that houses methods, practices, and policies.

Imas Kurniasih and Berlin Sani said that "the TPS learning model (think pairs share), is a learning model with a cooperative type designed and structured for interaction patterns between learners". ${ }^{13}$ The TPS model was first developed by Frang Lyman and his colleagues at the University of Maryland. This model is an appropriate and effective way to make the classroom discussion atmosphere more optimal. The procedure used in this model is to provide opportunities for learners to respond and help each other and give learners more time to think and interact with other learners.

In the learning process using the TPS (think pairs share) model, this model uses the atmosphere of class discussions by involving small groups, with the number of members of two people heterogeneously, starting with the provision of materials, group activities, and meetings. This model can

and Attitude," International Journal of Research in Teacher Education 5, no. 2 (2014): 1123, https://ijrte.penpublishing.net/makale/145.

${ }^{11}$ DePorter dan Hernacki, Quantum Learning: Membiasakan Belajar Nyaman dan Menyenangkan, 12.

${ }^{12}$ Miftahul Huda, Model-Model Pengajaran dan Pembelajaran : Isu-Isu Metodis dan Paradigmatis (Yogyakarta: Pustaka Pelajar, 2017), 109.

${ }^{13}$ Imas Kurniasih dan Berlin Sani, Ragam Pengembangan Model Pembelajaran untuk Peningkatan Profesionalitas Guru (Jakarta: Kata Pena, 2015), 58. 
provide opportunities for learners to respond and help each other and give learners more time to think and interact with other learners.

\section{Learning Motivation}

The word motivation is widely used in various fields and situations, but in this paper, it will be more focused on education, especially in learning. Learning motivation is a situation that exists in an individual where there is an urge to do something to achieve a goal. According to Mc Donald, explains that "motivation is a change in energy in a person characterized by the onset of affective (feelings) and reactions to achieve goals". ${ }^{14}$ Thus the appearance of motivation is characterized by a change in energy in a person that can be realized or not. The term Motivation (more), according to Bimo Walgito in Erjati Abbas, means "to move". Thus, motivation is defined as the power within the organism that encourages or is a driving force. ${ }^{15}$ The reason itself in English is motivation, which means mobilizer. Therefore, some say that "motives drive at me" or motifs that move me. ${ }^{16}$

Clayton Alderfer, in Nashar, explains, "motivation is a tendency of learners to do learning activities driven by a desire and desire to achieve the best possible learning outcomes or achievements". ${ }^{17}$ Based on some of the above understandings, it can be concluded that learning motivation is an encouragement that arises inside and outside a person or learner in acting to achieve the best possible learning results or achievements.

\section{Mastery of Arabic Vocabulary (Mufradat)}

The General Dictionary of Indonesian language interprets mastery as a real understanding of a field of science, or it can also mean experience or skill (against a speech or a science). ${ }^{18}$ In the Great Dictionary of The Indonesian Language, the meaning of mastery is the understanding and ability to use (cleverness, knowledge). ${ }^{19}$ While the definition of Vocabulary in Arabic is called mufradat, and in English, Vocabulary is a set of words or Vocabulary that is understood by someone or other ethnicities that is part of

${ }^{14}$ Kompri, Motivasi Pembelajaran Perspektif Guru dan Siswa (Bandung: Rosda Karya, 2015), 229.

${ }^{15}$ Erjati Abbas, Magnet Kepemimpinan Kepala Madrasah Terhadap Kinerja Guru (Jakarta: PT Elex Media Komputindo, 2017), 218.

${ }^{16}$ Abbdorrakhman Ginting, Esensi Praktis Belajar dan Pembelajaran (Bandung: Humaniora, 2008), 86.

${ }^{17}$ Nashar, Peranan Motivasi dan Kemampuan Awal dalam Kegiatan Pembelajaran (Jakarta: Delia Press, 2004), 42.

${ }^{18}$ Badadu dan Zain, Kamus Umum Bahasa Indonesia (Jakarta: Pustaka Sinar Harapan, 1996), 726.

${ }^{19}$ Departemen Pendidikan Nasional, Kamus Besar Bahasa Indonesia (Jakarta: Balai Pustaka, 2001), 604. 
a particular language. According to Horn, Vocabulary is a collection of stories that make up a language..$^{20}$

From the above understanding, the author can conclude that mastery of Vocabulary (mufradat) is one's understanding or skill in understanding the Arabic vocabulary (mufradat).

\section{Research methods}

This research is quantitative research with quasi-experimental type, in which the population in this study is students of Class VII MTs As'adiyah Banua Baru, the year of lesson 2019/2020 with a total of 96 learners spread into four classes with a study sampling of 42 students, consisting of 20 people from grade VII B as a control class, and 22 people from class VII C as practical classes. The sampling technique is purposive sampling, which is carried out with a subjective assessment of researchers with observations that have been done by looking at several considerations.

Data collection methods used by the authors in this study, namely observations, questionnaires and tests. The research instruments used are 1) observation guidelines used to measure data on the implementation of quantum learning in RPP (Learning Implementation Plan), as for the criteria to fill in the observation sheet is to give a tick " $\sqrt{ }$ " in the "implemented" column if the observed aspects of the RPP (Learning Implementation Plan) are carried out, and the "not implemented" column if the observed aspects of the RPP are not carried out. Each observation will be given a score of 1 if the statement is carried out and given 0 if the mention is not carried out. All collected scores will be summed up and searched for percentage ranges and categories, 2) student motivation questionnaires will be obtained by using questionnaire instruments as many as 20 items of statements in the form of a checklist with a Likert scale (1 to 4 ) to measure the learning motivation of learners given before and after learning, both in the control class and in the experimental class, 3) and the pretest and posttest question items in the form of multiple-choice questions totaling 25 questions, to measure data mastery of Arabic vocabulary learners experiment class and control class yeng obtained from pretest before treatment and posttest after treatment. The data analysis techniques used are descriptive statistical analysis and inferential statistical analysis with SPSS 22 for windows program applications.

In general, this study aims to determine the difference in effectiveness between the quantum learning model and the TPS learning model, reviewed from learning motivation and mastery of Arabic vocabulary of learners in MTs As'adiyah Banua Baru, Polewali Mandar district.

${ }^{20}$ Syaiful Mustofa, Strategi Pembelajaran Bahasa Arab Inovatif (Malang: UIN Malang Press, 2011), 61. 


\section{Results and Discussion}

\section{a. Descriptive Statistical Analysis}

This study's data are three types, namely RPP implementation data, learning motivation data, and Arabic vocabulary mastery data of learners. RPP implementation data is obtained from the RPP implementation observation sheet filled by observers. The learners' motivational information is obtained from the questionnaire of learning motivation that the learners have filled. Data mastery of Arabic vocabulary learners obtained from the learner's pretest and posttest values has been done. The description of the results for each data is as follows:

\section{1) RPP Implementation Data}

In this study, there were six meetings, both in the control class and the practical level. In the first meeting and the last meeting, each class is given a pretest and posttest. Students in the control class and experiment class carry out learning with al-adawat al-madrasiyah and al-alwan materials with different treatment from the second to the fourth meeting.

Observation of RPP implementation is carried out at every learning meeting. The performance of learning in each class is adjusted to the RPP that researchers have created. The implementation of RPP is analyzed by calculating IJA (Inter Judge Agreement) to determine what percentage of RPP implementation in the learning process. The results of the IJA calculation of RPP implementation in the control class and experiment class can be seen in Table 4.1, as follows:

Tabel 4.1 Data keterlaksanaan RPP

\begin{tabular}{cccccc}
\hline Class & Meeting & Meeting & Meeting & Meeting & Average \\
\hline Control Class & $77,78 \%$ & $88,89 \%$ & $94,44 \%$ & $100 \%$ & $90,28 \%$ \\
\hline Experiment Class & $88,89 \%$ & $94,44 \%$ & $100 \%$ & $100 \%$ & $95,83 \%$ \\
\hline
\end{tabular}

Based on Table 4.1, it appears that the average RPP performance value in the control class is $90.28 \%$, and the experiment class is $95.83 \%$, so that it can be categorized very well.

\section{2) Learning Motivation Data}

There are two learning motivation data of learners, namely early learning motivation and final learning motivation. The initial learning motivation is obtained from the learning motivation questionnaire given to the learners at the first meeting. The final learning motivation is obtained from the questionnaire of learning motivation presented at the sixth meeting. The motivational questionnaire of learning is in the form of 
statement details with four choices of answers. The motivational data of education, both beginning, and end, is obtained by summing each item of statement that respondents or learners have filled. The results of learning motivation data of control class learners and practical classes can be seen in Table 4.2, as follows:

Table 4.2 Learner Learning Motivation Data in Control Classes and Experimental Classes

\begin{tabular}{ccccc}
\hline \multirow{2}{*}{ Statistical Score } & \multicolumn{2}{c}{$\begin{array}{c}\text { Early Learning } \\
\text { Motivation }\end{array}$} & \multicolumn{2}{c}{$\begin{array}{c}\text { Final Learning } \\
\text { Motivation }\end{array}$} \\
\cline { 2 - 5 } & $\begin{array}{c}\text { Control } \\
\text { Class }\end{array}$ & $\begin{array}{c}\text { Experiment } \\
\text { Class }\end{array}$ & $\begin{array}{c}\text { Control } \\
\text { Class }\end{array}$ & $\begin{array}{c}\text { Experiment } \\
\text { Class }\end{array}$ \\
\hline Students & 20 & 22 & 20 & 22 \\
\hline Highest Score & 71 & 73 & 73 & 79 \\
\hline Lowest Score & 50 & 50 & 59 & 61 \\
\hline Average Score & 58,10 & 59,68 & 64,60 & 68,27 \\
\hline Variance & 35,67 & 22,80 & 14,25 & 20,78 \\
\hline Standard Deviation & 5,97 & 4,78 & 3,78 & 4,56 \\
\hline
\end{tabular}

\section{3) Data Mastery of Arabic Vocabulary}

In this study, data mastery of learners' Arabic vocabulary is two, namely initial ability data and final camp data. Learners' initial ability data is obtained from the pretest conducted at the first meeting before learning. The learner's last ability data is obtained from the posttest conducted at the sixth meeting after the learning is completed. Pretest and postest in the form of multiple-choice questions totaling 25 questions. Data on initial ability and mastery of Arabic vocabulary of learners can be seen in Table 4.3, as follows:

Table 4.3. Results of Mastery of Arabic Vocabulary Beginning and End of Learning in Control Classes and Experimental Classes

\begin{tabular}{ccccc}
\hline \multirow{2}{*}{ Statistical Score } & \multicolumn{2}{c}{ Pretest } & \multicolumn{2}{c}{ Postest } \\
\cline { 2 - 5 } & $\begin{array}{c}\text { Control } \\
\text { Class }\end{array}$ & $\begin{array}{c}\text { Experiment } \\
\text { Class }\end{array}$ & $\begin{array}{c}\text { Control } \\
\text { Class }\end{array}$ & $\begin{array}{c}\text { Experiment } \\
\text { Class }\end{array}$ \\
\hline Students & 20 & 22 & 20 & 22 \\
\hline Highest Score & 80 & 92 & 92 & 100 \\
\hline Lowest Score & 24 & 20 & 64 & 56 \\
\hline Average Score & 47,60 & 42,18 & 77,20 & 81,45 \\
\hline Variance & 237,30 & 337,87 & 87,75 & 217,21 \\
\hline Standard Deviation & 15,40 & 18,38 & 9,37 & 14,74 \\
\hline
\end{tabular}




\section{b. Inferential Statistical Analysis}

Inferential statistical analysis is used to test research hypotheses using ttests. But before testing this hypothesis, it is first done normality test and data homogeneity test.

\section{1) Normality Test}

Normality tests are performed to see if the data obtained is distributed normally or not. The data normality test in this study is the KolmogorovSmirnov test with SPSS 22 for windows. Data can be declared generally distributed if Nila Asylum. Sig is more significant than 0.05 . The results of the data normality test obtained in this research are as follows:

\section{a. Learning Motivation Data}

The results of the normality test of the initial and final learning motivation data in the experiment class and control class can be seen in Table 4.4 as follows:

Table 4.4 Results of Normality Test Of Learning Motivation Data for Experimental Classes and Control Classes

\begin{tabular}{llccc}
\hline & \multicolumn{1}{c}{ Kelas } & \multicolumn{3}{c}{ Kolmogorov-Smirnov } \\
\cline { 3 - 5 } & Statistic & df & Sig. \\
\hline & $\begin{array}{l}\text { Early Motivation of Experimental } \\
\text { Classes }\end{array}$ & .181 & 22 & $\mathbf{. 0 6 0}$ \\
$\begin{array}{l}\text { Student } \\
\text { Learning } \\
\text { Motivation }\end{array}$ & Final Motivation Of Experimental Class & .146 & 22 & $\mathbf{. 2 0 0}^{*}$ \\
\cline { 2 - 6 } & Early Motivation Control Class & .173 & 20 & $\mathbf{. 1 1 8}$ \\
\cline { 2 - 6 } & Final Motivation Control Class & .164 & 20 & $\mathbf{. 1 6 3}$ \\
\hline
\end{tabular}

Based on table 4.4 above shows that the normality test of early and final learning motivation data in the control class and the experimental class obtained a higher significance value of 0.05 , it can be concluded, that in control classes and experimental classes, early learning motivation data before and after the normally distributed learning model is applied.

b. Data Mastery of Arabic Vocabulary

The results of the normality test of the initial and final vocabulary mastery data in the experiment class and control class can be seen in Table 4.5 as follows:

Table 4.5 Results of Normality Test Data Result of Vocabulary Mastery of Learners Experimental Class and Control Class 


\begin{tabular}{|c|c|c|c|c|}
\hline & \multirow{2}{*}{ Kelas } & \multicolumn{3}{|c|}{ Kolmogorov-Smirnova } \\
\hline & & Statistic & df & Sig. \\
\hline \multirow{4}{*}{$\begin{array}{l}\text { Vocabulary } \\
\text { Mastery Results }\end{array}$} & Pre-Test Experimental Classes & .143 & 22 & $.200^{*}$ \\
\hline & $\begin{array}{l}\text { Post-Test Experimental } \\
\text { Classes }\end{array}$ & .172 & 22 & .090 \\
\hline & Pre-Test Control Class & .192 & 20 & .051 \\
\hline & Post-Test Control Class & .187 & 20 & .065 \\
\hline
\end{tabular}

Based on table 4.5 above shows that the normality test of Arabic vocabulary mastery data beginning and end in the control class and experiment class obtained a significance value greater than 0.05 ; it can be concluded that in control classes and practical classes, data mastery of Arabic vocabulary learners before and after applied regular distributed learning models.

\section{2) Homogeneity Test}

In this study, researchers used the Levene test utilizing the help of the SPSS 22 program application. Where the data is declared homogeneous if the significance value is more significant than 0.05 . The results of the homogeneity test data obtained are as follows:

\section{a. Learning Motivation Data}

The results of the calculation of the homogeneity test of learners' learning motivation data by using the SPSS program can be seen in Table 4.6 as follows:

Table 4.6 Hasi Homogeneity Test Data Motivation of Early Learning and Motivation of Final Learning of Learners

\begin{tabular}{lrrrr}
\hline & $\begin{array}{c}\text { Levene } \\
\text { Statistic }\end{array}$ & df1 & df2 & Sig. \\
\cline { 2 - 5 } Early Learning Motivation & 1.972 & 1 & 40 & $\mathbf{. 1 6 8}$ \\
\hline Final Learning Motivation & .608 & 1 & 40 & $\mathbf{. 4 4 0}$ \\
\hline
\end{tabular}

Table 4.6 shows that early learning motivation data has a significance greater than $0.05(0.810>0.05)$. It can be disimp[ulkan, that learners' initial learning motivation has a homogeneous data variance. While learners' final learning motivation also has a significance value greater than $0.05(0.440>0.05)$, it can be concluded that learners' final learning motivation has homogeneous data variance. 


\section{b. Data Mastery of Arabic Vocabulary}

The homogeneity test results of Arabic vocabulary mastery data of learners are seen in table 4.7 as follows:

Table 4.7 Results of Homogeneity Test of Ability Beginning and End mastery of Arabic Vocabulary Learners

\begin{tabular}{lrrrr}
\hline & Levene Statistic & df1 & df2 & Sig. \\
\cline { 2 - 5 } Initial Capability & .530 & 1 & 40 & $\mathbf{. 4 7 1}$ \\
\hline final ability & 6.607 & 1 & 40 & $\mathbf{. 0 1 4}$ \\
\hline
\end{tabular}

Based on Table 4.7 shows that the initial capability data has a significance value greater than $0.05(0.471>0.05)$ so that it can be concluded that the initial ability of learners has homogeneous data variance. In contrast, the absolute power of the learner has a significance value less than $0.05(0.014<0.05)$ so that it can be concluded that the final ability of mastery of Arabic vocabulary learners has variances of data that are not homogeneous.

\section{c. Hypothesis Testing}

1) Testing hypothesis effectiveness of quantum learning model and TPS learning model reviewed from learner learning motivation

a) Hypothesis test the effectiveness of quantum learning model is reviewed from the learning motivation of learners.

Hypothetical testing of quantum learning models' effectiveness on learners' learning motivation was conducted through paired T-test. In this case, $\mathrm{Ha}$ is accepted, and $\mathrm{Ho}$ is rejected if the significance value is less than 0.05 or the value of $\operatorname{sig}<$ is 0.05 (with a confidence interval of $95 \%$ ). The formulation of the hypothesis in question is as follows:

Ho = Quantum learning model is not effective against learners' learning motivation

$\mathrm{Ha}=$ Quantum learning model is effective against learners' learning motivation

Paired T-test results in the experiment class can be described in table 4.8 as follows:

Table 4.8 Results of Paired T-test Questionnaire Motivation to Learn Experimental Class 


\begin{tabular}{|c|c|c|c|c|c|c|c|c|}
\hline \multicolumn{9}{|c|}{ Paired Samples Test } \\
\hline & \multicolumn{5}{|c|}{ Paired Differences } & \multirow[b]{3}{*}{$\mathrm{t}$} & \multirow[b]{3}{*}{$\mathrm{df}$} & \multirow{3}{*}{$\begin{array}{l}\text { Sig. (2- } \\
\text { tailed) }\end{array}$} \\
\hline & \multirow[b]{2}{*}{ Mean } & \multirow{2}{*}{$\begin{array}{c}\text { Std. } \\
\text { Deviation }\end{array}$} & \multirow{2}{*}{$\begin{array}{l}\text { Std. } \\
\text { Error } \\
\text { Mean }\end{array}$} & \multicolumn{2}{|c|}{$\begin{array}{l}\text { 95\% Confidence } \\
\text { Interval of the } \\
\text { Difference }\end{array}$} & & & \\
\hline & & & & Lower & Upper & & & \\
\hline $\begin{array}{l}\text { Early Motivation of } \\
\text { Experimental Class - } \\
\text { Final Motivation of } \\
\text { Experimental Class }\end{array}$ & -8.591 & 4.768 & 1.016 & -10.705 & -6.477 & -8.452 & 21 & .000 \\
\hline
\end{tabular}

Based on table 4.8, obtained asym value. Sig. (2-tailed) smaller than $0.05(0.000<0.05)$. This indicates that Ha was accepted and Ho was rejected. Thus, the application of the quantum learning model is effective to the learning motivation of learners.

b) Hypothesis test the TPS model's effectiveness (think pairs share) is reviewed from learners' learning motivation.

Hypothesis testing the TPS model's effectiveness (think pairs share) on learner learning motivation, conducted through Paired T-test. In this case, Ha is accepted, and Ho is rejected if the significance value is less than 0.05 or the sig value. $<0.05$ (with a confidence interval of 95\%). The formulation of the hypothesis in question is as follows:

Ho $=$ TPS model (think pairs share) is not effective against the learning motivation of learners

$\mathrm{Ha}=$ TPS model (think pairs share) is effective against the learning motivation of learners

Paired T-test results in the control class can be described in table 4.9, as follows:

Table 4.9 Test Results Paired T-test Motivational Questionnaire Learning Control Class

\begin{tabular}{|c|c|c|c|c|c|c|c|c|}
\hline \multicolumn{9}{|c|}{ Paired Samples Test } \\
\hline & \multicolumn{5}{|c|}{ Paired Differences } & \multirow[b]{4}{*}{$\mathrm{t}$} & \multirow[b]{4}{*}{ df } & \multirow{4}{*}{$\begin{array}{l}\text { Sig. } \\
(2- \\
\text { tailed })\end{array}$} \\
\hline & \multirow[b]{3}{*}{ Mean } & \multirow{3}{*}{$\begin{array}{c}\text { Std. } \\
\text { Deviation }\end{array}$} & \multirow{3}{*}{$\begin{array}{l}\text { Std. } \\
\text { Error } \\
\text { Mean }\end{array}$} & \multirow{2}{*}{\multicolumn{2}{|c|}{$\begin{array}{l}95 \% \text { Confidence } \\
\text { Interval of the } \\
\text { Difference }\end{array}$}} & & & \\
\hline & & & & & & & & \\
\hline & & & & Lower & Upper & & & \\
\hline $\begin{array}{l}\text { Early Motivation of } \\
\text { Control Class - } \\
\text { Final Motivation of } \\
\text { Control Class }\end{array}$ & -6.500 & 6.387 & 1.428 & -9.489 & -3.511 & -4.551 & 19 & .000 \\
\hline
\end{tabular}


Based on table 4.9, obtained asym value. Sig. (2-tailed) smaller than $0.05(0.000<0.05)$. Therefore, Ha is accepted, and Ho is rejected. Thus, the TPS Model (think pairs share) in the control class is effective against learners' learning motivation.

2) Hypothesis test the effectiveness of quantum learning model and TPS learning model (think pairs share) reviewed from mastery of Arabic vocabulary learners

a) Hypothesis test the effectiveness of quantum learning model reviewed from mastery of Arabic vocabulary

To test the hypothesis of the effectiveness of quantum learning model on mastery of Arabic vocabulary of learners, paired T-test was conducted. in this case, $\mathrm{Ha}$ is accepted, and Ho is rejected if the value ( $\mathrm{sig})<0.05$ or the significance value is less than 0.05 (with a confidence interval of $95 \%$ ). The hypothetical formulation is as follows:

Ho = Quantum learning model is not effective against the mastery of Arabic vocabulary of learners

$\mathrm{Ha}=$ Quantum learning model is effective against the mastery of Arabic vocabulary learners

Paired T-test results in the experimental class can be seen in Table 4.10 as follows:

Table 4.10 Test Results Paired T-test Mastery of Arabic Vocabulary Experimental Class

\begin{tabular}{|c|c|c|c|c|c|c|c|c|}
\hline \multicolumn{9}{|c|}{ Paired Samples Test } \\
\hline & \multicolumn{5}{|c|}{ Paired Differences } & \multirow[b]{3}{*}{$\mathrm{t}$} & \multirow[b]{3}{*}{ df } & \multirow{3}{*}{$\begin{array}{l}\text { Sig. } \\
(2- \\
\text { tailed })\end{array}$} \\
\hline & \multirow[b]{2}{*}{ Mean } & \multirow{2}{*}{$\begin{array}{c}\text { Std. } \\
\text { Deviation }\end{array}$} & \multirow{2}{*}{$\begin{array}{l}\text { Std. } \\
\text { Error } \\
\text { Mean }\end{array}$} & \multicolumn{2}{|c|}{$\begin{array}{l}95 \% \text { Confidence } \\
\text { Interval of the } \\
\text { Difference }\end{array}$} & & & \\
\hline & & & & Lower & Upper & & & \\
\hline $\begin{array}{l}\text { Pretest-Postest } \\
\text { Experimental } \\
\text { Class }\end{array}$ & -39.273 & 16.774 & 3.576 & -46.710 & -31.836 & -10.982 & 21 & .000 \\
\hline
\end{tabular}

Table 4.10 shows the value of Asym. Sig. (2-tailed) smaller than $0.05(0.000<0.05)$. Therefore, $\mathrm{Ha}$ is accepted, and $\mathrm{Ho}$ is rejected. Thus, it can be concluded that quantum learning models are effective against the mastery of the Arabic Vocabulary of learners. 
b) Hypothesis test the effectiveness of TPS learning model (think pairs share) reviewed from mastery of Arabic vocabulary of learners

We are testing the TPS learning model (think pairs share) in a control class based on mastery of Arabic vocabulary learners conducted through Paired T-test. In this case, $\mathrm{Ha}$ is accepted, and Ho is rejected if the value ( $\mathrm{sig})<$ is 0.05 or the significance value is less than 0.05 (with a confidence interval of $95 \%$ ). The hypothetical formulation is as follows:

Ho $=$ Model TPS (think pairs share) is not effective against the mastery of Arabic vocabulary of learners

$\mathrm{Ha}=$ Model TPS (think pairs share) effective against the mastery of Arabic vocabulary learners

Paired T-test results in the control class can be seen in Table 4.11 as follows:

Table 4.11 Test Results Paired T-test Mastery of Arabic Vocabulary Control Class

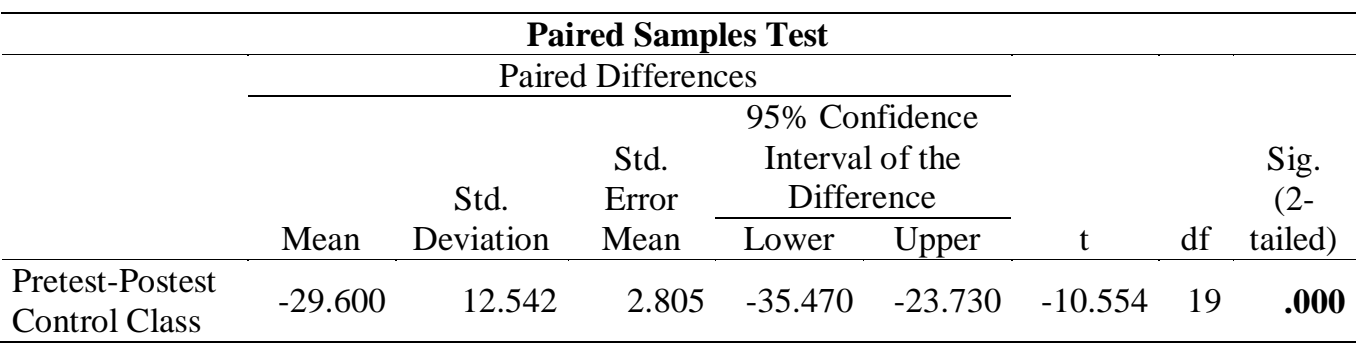

Table 4.11 shows that the value of Asymp. Sig. (2-tailed) smaller than $0.05(0.000<0.05)$. Therefore, Ha is accepted, and Ho is rejected. Thus, it can be said that the tps learning model (think pairs share) is effective against mastering the Arabic vocabulary of learners.

3) Hypothesis test the difference in effectiveness between the use of Quantum Learning model and TPS model (think pairs share) is reviewed from the learner's learning motivation.

Hypothetical testing of differences in the effectiveness of both learning models can be done through an independent sample t-test. In this case, Ho is rejected, and $\mathrm{Ha}$ is accepted if the value (sig) $<$ is 0.05 or the significance value is less than 0.05 . The formulation of the hypothesis in question is as follows: 
Ho = No difference in effectiveness between the use of quantum learning models and TPS learning models (think pairs share), reviewed from the learning motivation of learners

$\mathrm{Ha}=$ There is a difference in effectiveness between the use of quantum learning models and TPS learning models (think pairs share), reviewed from the learning motivation of learners

The results of the independent sample t-test can be seen in Table 4.12 as follows:

Table 4.12 Independent Test Results Sample T-test Learner Learning Motivation

\begin{tabular}{|c|c|c|c|c|c|c|c|c|c|}
\hline \multicolumn{10}{|c|}{ Independent Sample } \\
\hline \multirow{3}{*}{$\begin{array}{l}\text { Motivasi Belajar } \\
\text { Siswa }\end{array}$} & \multicolumn{9}{|c|}{ Levene's Test } \\
\hline & \multirow[t]{2}{*}{ F } & \multirow[t]{2}{*}{ Sig. } & \multirow[t]{2}{*}{$t$} & \multirow[t]{2}{*}{ df } & \multirow[t]{2}{*}{$\begin{array}{c}\text { Sig. } \\
(2- \\
\text { tailed) }\end{array}$} & \multirow[t]{2}{*}{$\begin{array}{c}\text { Mean } \\
\text { Difference }\end{array}$} & \multirow[t]{2}{*}{$\begin{array}{l}\text { Std. Error } \\
\text { Difference }\end{array}$} & \multicolumn{2}{|c|}{$\begin{array}{c}95 \% \\
\text { Confidence } \\
\text { Interval of } \\
\text { the } \\
\text { Difference }\end{array}$} \\
\hline & & & & & & & & Lower & Upper \\
\hline $\begin{array}{l}\text { Equal } \\
\text { assumed }\end{array}$ & .608 & .440 & 2.827 & 40 & .007 & 3.673 & 1.299 & 1.047 & 6.298 \\
\hline $\begin{array}{l}\text { Equal variences } \\
\text { not assumed }\end{array}$ & & & 2.853 & 39.678 & .007 & 3.673 & 1.287 & 1.070 & 6.275 \\
\hline
\end{tabular}

Based on table 4.12, obtained asymp value. Sig. (2-tailed) is less than $0.05(0.007<0.05)$. Therefore, Ha is accepted, and Ho is rejected. Thus, it can be concluded that there is a difference in effectiveness between the use of quantum learning models and TPS learning models (think pairs share), judging from learners' learning motivation.

4) Hypothesis test the difference in effectiveness between the use of quantum learning model and TPS model (think pairs share) reviewed from mastery of Arabic vocabulary learners

To test the hypothesis of differences in the two models' effectiveness, an independent sample t-test was conducted. In this case, $\mathrm{Ha}$ is accepted and Ho is rejected if the value (sig) $<0.05$ or the significance value is less than 0.05 . The formulation of the hypothesis in question is as follows:

Ho $=$ There is no difference in effectiveness between quantum learning model and TPS learning model (think pairs share), judging from mastery of Arabic vocabulary of learners

$\mathrm{Ha}=$ There is a difference in effectiveness between quantum learning models and TPS learning models (think pairs 
share), judging from the mastery of Arabic vocabulary of learners

Independent sample t-test results can be seen in Table 4.13 as follows:

Table 4.13 Results of Independent Test Sample T-test Mastery of Arabic Vocabulary Learners

\begin{tabular}{|c|c|c|c|c|c|c|c|c|c|}
\hline \multicolumn{10}{|c|}{ Independent Samples Test } \\
\hline \multirow{3}{*}{$\begin{array}{l}\text { Hasil Belajar } \\
\text { Siswa }\end{array}$} & \multicolumn{9}{|c|}{ Levene's Test } \\
\hline & \multirow[t]{2}{*}{ f } & \multirow[t]{2}{*}{ Sig. } & \multirow[t]{2}{*}{$t$} & \multirow[t]{2}{*}{ df } & \multirow[t]{2}{*}{$\begin{array}{l}\text { Sig. } \\
(2- \\
\text { tailed) }\end{array}$} & \multirow{2}{*}{$\begin{array}{c}\text { Mean } \\
\text { Difference }\end{array}$} & \multirow{2}{*}{$\begin{array}{l}\text { Std. Error } \\
\text { Difference }\end{array}$} & \multicolumn{2}{|c|}{$\begin{array}{l}95 \% \text { Confidence } \\
\text { Interval of the } \\
\text { Difference }\end{array}$} \\
\hline & & & & & & & & Lower & Upper \\
\hline $\begin{array}{l}\text { Equal variances } \\
\text { assumed }\end{array}$ & 6.607 & .014 & 1.104 & 40 & .276 & 4.255 & 3.855 & -3.537 & 12.047 \\
\hline $\begin{array}{l}\text { Equal } \\
\text { variances not } \\
\text { assumed }\end{array}$ & & & 1.127 & 35.962 & .267 & 4.255 & 3.776 & -3.404 & 11.914 \\
\hline
\end{tabular}

Based on table 4.13, obtained asymp value. Sig. (2-tailed) greater than $0.05(0.267>0.05)$. Thus, Ho is accepted, and Ha is rejected. Therefore, it can be concluded that there is no difference in effectiveness between the use of quantum learning models and TPS learning models (think pairs share), judging from the mastery of Arabic Vocabulary of learners.

\section{E. Research Discussion}

This research was conducted to analyze the differences in Arabic language learning effectiveness using quantum learning models and TPS learning models (think pairs share) reviewed from the motivation of learning and mastery of Arabic vocabulary of learners. This research was conducted in MTs As'adiyah Banua Baru, Polewali Mandar Regency. In this study, the samples were class VII B as control class, namely class with TPS model (think pairs share), and class VII $\mathrm{C}$ as an experimental class, namely class with quantum learning model. The materials taught in both categories are al-adawat al-madrasiyah and al-alwan. The study was conducted in six face-to-face meetings. In the first face-to-face pretest and questionnaire of early learning motivation, face-to-face second to fifth learning is carried out with each learning model. The sixth face-to-face is done posttest and final learning motivation questionnaire.

In the data description, the implementation of learning models in control classes and practical classes is analyzed with IJA to determine the percentage level of RPP implementation in the learning process. IJA calculation of RPP implementation in the control class and experiment class showed that the mean or average RPP in the control class is $90.28 \%$, and the experiment class is $95.83 \%$. However, the implementation of RPP in each type has a difference in a mean or average value. The average 
performance of RPP in the experiment class with the quantum learning model has a higher average value of $95.83 \%$. In contrast, the control class with the TPS model (think pairs share) has an average value of $90.28 \%$. Still, both models can be categorized as very well executed, and it appears that the active involvement of learners in learning.

In the data description, the motivation and results of mastery of Arabic vocabulary used as a control and the class used as an experiment experienced an increasing average score. The mean or average score of learning motivation in the control class increased from 58.10 to 64.60, while in the experiment class, it grew from 59.68 to 68.27 . The average score of control class vocabulary mastery risen from 47.60 to 77.20 , while the experiment class increased from 42.18 to 81.45 .

Based on the research done, then analyzed using the SPSS 22 program for windows, the researchers conducted an independent sample t-test to test the difference in effectiveness of the two models based on learners' learning motivation of learners Asymp value. Sig. (2-tailed) is less than $0.05(0.007<$ 0.05). The average motivation score of the final learning class of 68.27 is greater than the final learning control class's average motivation score, 64.60. Thus it can be said that quantum learning models in the experimental class are more effective than the TPS learning model (think pairs share) in the control class, While the independent sample t-test to see the difference in the effectiveness of the two learning models was reviewed from the mastery of Arabic Vocabulary of learners, obtained the value of Asymp. Sig. (2-tailed) on equal variances not assumed greater than $0.05(0.267>0.05)$. Therefore, it showed no significant difference between the Arabic vocabulary mastery data of practical classes and control classes. However, there was a difference in the average mean score in both models in the mastery of Arabic vocabulary of learners, namely in the experiment class 81.45 greater than the average learning score of the control class 77.20. Thus, it can be concluded that the quantum learning model in the experimental class and the TPS learning model (think pairs share) in the control class are both effective but do not have significant differences in effectiveness judging from the mastery of the Learner's Arabic vocabulary.

\section{F. Conclusion}

The results obtained in this study showed that quantum learning models in practical classes and TPS learning models (think pairs share) in control classes are classified as useful because they experience an increase in average value. However, on the differences in the effectiveness of the two learning models reviewed from learning motivation, there are significant differences by looking at Asymp's value. Sig. (2-tailed) is less than 0.05 (0.007 <0.05), with Ho's conclusion rejected and Ha accepted, or the 
quantum learning model more effective than the TPS learning model (think pairs share) reviewed from the learner's learning motivation. However, in the mastery of the Learner's Arabic vocabulary, there was no significant difference with The Asymp. Sig. (2-tailed) a value greater than $0.05(0.267$ $>0.05$ ), with Ho's conclusion, accepted and Ha, rejected, or the quantum learning model and TPS learning model (think share pairs) both practical but had no difference in effectiveness reviewed from the mastery of the Learner's Arabic vocabulary. From the above exposure, it can be concluded that the improvement of learning motivation and ability of Arabic vocabulary of learners can be made by choosing a good and varied learning model so that there are a spirit and inspiration from learners to continue learning. Educators should plan suitable learning activities by choosing learning methods and models that match the materials to be delivered to learners and pay attention to different learners' environmental conditions and character. 


\section{References}

Abbas, Erjati. Magnet Kepemimpinan Kepala Madrasah Terhadap Kinerja Guru. Jakarta: PT Elex Media Komputindo, 2017.

ACAT, M. Bahaddin, dan Yusuf Ay. "An Investigation the Effect of Quantum Learning Approach on Primary School 7th Grade Students' Science Achievement, Retention and Attitude." International Journal of Research in Teacher Education 5, no. 2 (2014): 11-23. https://ijrte.penpublishing.net/makale/145.

Andini, Deassy May, dan Endang Supardi. "Kompetensi Pedagogik Guru Terhadap Efektivitas Pembelajaran Dengan Variabel Kontrol Latar Belakang Pendidikan Guru." Jurnal Pendidikan Manajemen Perkantoran (JPManper) 3, no. 1 (2018): 1-7. https://doi.org/10.17509/jpm.v3i1.9450.

Ardiansyah, Muhammad Beben Satria. "Analisis Faktor Kesulitan Membaca Teks Berbahasa Arab Pada Siswa Kelas X IIS 1 Madrasah Aliyah Negeri Wonokromo Bantul Yogyakarta Tahun Ajaran 2016/2017." Skripsi, UIN Sunan Kalijaga Yogyakarta, 2017. http://digilib.uinsuka.ac.id/25252/.

Arsyad, Azhar. Bahasa Arab dan Metode Pengajarannya: Beberapa Pokok Pikiran. Yogyakarta: Pustaka Pelajar, 2003.

Badadu dan Zain. Kamus Umum Bahasa Indonesia. Jakarta: Pustaka Sinar Harapan, 1996.

Departemen Pendidikan Nasional. Kamus Besar Bahasa Indonesia. Jakarta:

Balai Pustaka, 2001.

DePorter, Bobbi, dan Mike Hernacki. Quantum Learning: Membiasakan

Belajar Nyaman dan Menyenangkan. Diterjemahkan oleh Alwiyah

Abdurrahman. Bandung: Kaifa, 2011.

Echols, John M., dan Hassan Shadily. Kamus Inggris Indonesia. Jakarta:

Gramedia Pustaka Utama, 2000.

Ginting, Abbdorrakhman. Esensi Praktis Belajar dan Pembelajaran.

Bandung: Humaniora, 2008.

Huda, Miftahul. Model-Model Pengajaran dan Pembelajaran : Isu-Isu

Metodis dan Paradigmatis. Yogyakarta: Pustaka Pelajar, 2017.

Kompri. Motivasi Pembelajaran Perspektif Guru dan Siswa. Bandung: Rosda Karya, 2015.

Kurniasih, Imas, dan Berlin Sani. Ragam Pengembangan Model

Pembelajaran untuk Peningkatan Profesionalitas Guru. Jakarta: Kata

Pena, 2015. 
Mustofa, Syaiful. Strategi Pembelajaran Bahasa Arab Inovatif. Malang: UIN Malang Press, 2011.

Nashar. Peranan Motivasi dan Kemampuan Awal dalam Kegiatan

Pembelajaran. Jakarta: Delia Press, 2004.

Rohmawati, Afifatu. "Efektivitas Pembelajaran." Jurnal Pendidikan Usia Dini 9, no. 1 (2015): 15-32.

http://journal.unj.ac.id/unj/index.php/jpud/article/view/3491.

Sanjaya, Wina. Strategi Pembelajaran Berorintasi Standar Proses

Pendidikan. Jakarta: Kencana, 2006. 
The Effectiveness of Quantum Learning to Increase Motivation and ... | 280 